\title{
Journal Writing and Diary Journal Writing: Effects on Students' Writing Proficiency and Student and Teacher Attitudes
}

\author{
*Aynur Yürekli ${ }^{1}$, Anita Afacan² \\ School of Foreign Languages ${ }^{1,2}$ \\ İmir University of Economics, School of Foreign Languages \\ Address: Fevzi Çakmak, Sakarya Cd. No:156, 35330 \\ Balçova/İzmir, Turkey \\ Phone: +902322792525 \\ E-mail: aynur.yurekli@ieu.edu.tr ${ }^{1}$, anita.afacan@ieu.edu.tr ${ }^{2}$ \\ ${ }^{*}$ Corresponding Author \\ DOI: https://doi.org/10.18326/rgt.v13i1.1-48
}

\section{Submission Track:}

Received: 31-03-2020

Final Revision: 23-05-2020

Available online: $01-06-2020$

\begin{abstract}
In today's world, writing is no longer a natural activity, especially for the younger generation. They look upon this activity as too complex, overwhelming and sometimes irrelevant. These attitudes are amplified when having to write in a second language. In EFL tertiary education, the expectations of academic achievement have become far greater than actual student capabilities. This study examined the possibility of using journal writing, both with and without an audience, as a way to address this issue. It is believed that by engaging
\end{abstract}


students in the act of writing without the burden of an academic topic, it will indirectly impact students' academic performance. Seventy-six undergraduate students in three groups (one control and two experimental) were involved. Data was collected in the form of pre-test and post-test writing, student focus group meetings and an interview with the instructor. From the study, it was found that dialogue journal writing with an audience contributed to an increase in the proficiency level of students, especially in terms of their organizational skills. In addition, students who undertook journal writing expressed gains in self-confidence, and were aware of the role of journal writing in this. Finally, journal writing was found to offer insight to the instructor with regard to what is happening under the surface of a class, and thus better address students' needs.

Keywords: EFL, academic writing, writing proficiency, journal writing

\section{INTRODUCTION}

Along with the advancements in technology, the basic skills involved in academic and daily communication have changed drastically. Especially, when it comes to the skill of writing, the younger generation employs various new means of communication. They use signs, abbreviations, symbols, which are quicker and less ambiguous in expressing themselves. For example, rather than writing "I like this photo", they press a heart button, which transfers the message effortlessly in less than a second. Therefore, we are dealing with a generation that does not write as a part of everyday communication because they see little value in it, and as a skill, it has started losing its authenticity.

Yet, at college, students are reminded about "writing" sentences, paragraphs and essays, which seems to be one of the rare contexts where students are expected not only to write, but to write academically. The literature on skills development suggests that writing is the hardest skill in 
which to acquire competency because it is the least practiced (Hamp and Heasly, 2006: 2). If we look at all four skills, we can easily claim that speaking and listening are encountered on a regular basis, both in everyday communication and academic environments as part of classroom interaction. The skill of reading is key to many sources and is practiced quite often, including internet searches (requiring constant skimming and scanning), class assignments, and leisure reading. Yet, for the vast majority, writing, especially of extended texts, is limited to course work.

As one EFL teacher expresses it, getting students to write is a challenge because students are rarely encouraged or asked to write anything of any length in their lives. As Seaboyer and Barnett (2018) put it, there is a 'disability' among university students regarding writing, and the desire and motivation has perished. When we consider the EFL setting, the situation gets more complicated because students are expected not only to write academically, but also to do so in another language (Rafida, 2017). As Breeze (2012) foregrounds, "the novel cognitive demands of university work are exacerbated by linguistic difficulties, so that the task of writing a paper or an exam answer is doubly complicated (p.9)."

EFL students at the tertiary level have two main challenges: a) regain or re-train their existing writing skills, and b) adapt these to the academic writing genre in English, a language in which they are usually not quite competent. Therefore, the writing curriculum needs to address both needs so that students are confident in the skill of writing and also able to transfer this confidence into the academic writing context. Thus, the main motivation underlying this 
study is to offer writing instructors an insight on how to help students practice writing communicatively by creating a positive attitude towards writing through journals and dialogue journals. The advantages of journal writing are numerous, yet whether journal entries should receive feedback from the teacher or kept personal is inconclusive. This study aims to shed light on which of the two impact students' academic writing proficiency more, and which affects their attitude more positively towards writing.

\section{Challenges of writing in EFL}

To understand specifically what is required from students, we need to look at rubrics used to grade students' writing, especially essays. A glance at EAP essay writing criteria reveals a variety of rubrics available, and the majority have four common components, even though they may be labelled differently (Hawkey and Barker, 2004). One is task achievement or content, which generally refers to the extent of content coverage, and how it relates to the task specifications. In task achievement, students are basically expected to generate ideas and information needed to respond to the task. Another component refers to how well students use language, labelled variously as accuracy, language use, or lexical/syntactic resources. The third component relates to how well students organize their ideas, usually referred to as 'organization' or 'coherence \& cohesion'. Finally, there is writing fluency, which refers to the amount produced, and its meaningfulness and relevance considering the given time limitations.

The components in the scoring rubrics are also an indication of what is expected of students' writings. To sum up the expectations, students in an EFL 
setting are generally required to be fluent and accurate writers, capable of generating content, organizing it in accordance with academic conventions, and demonstrating these skills in their second or additional language, English.

When considering typical writing practice and instruction, it is not unusual to find that minimal attention is devoted to empowering students with writing fluency. It is assumed that writing is learned by practicing, so students are directly exposed to the writing task or assignment. The usual pattern is as follows: initiating the topic, which covers the purpose, guidelines and task specifications about the writing; selection of a topic; supervision and feedback; and finally, evaluation and assessment (Kruse, 2013). As a result, it is assumed, often wrongly, that students are motivated, and the only action needed is to help them structure content in compliance with academic conventions. The fact that writing is rarely practiced and considered redundant in terms of everyday use is frequently overlooked.

Moreover, writing in a foreign language has a complicated and multifaceted nature, and there are different orientation towards writing that shape classroom methodologies. Hyland (2016) refers to six different paradigms; namely writing as expressive activity, cognitive activity, completed activity, situated activity, social activity and ideology. As applied in academic settings at university level, the product is given priority over all other perspectives; i.e., writing is seen as a completed activity. Isolating this communicative skill to the product only, also misleads writing teachers who eventually limit their feedback on linguistic features of the written text, with little value on writing as an expressive activity (Hubert and Bonzo, 2019). 
However, writing is recursive, and the text is only the final product of the complex composing process. This is one major reason for the rise of process writing.

\section{Process writing}

As opposed to product-oriented approaches to writing, process writing foregrounds the stages that lead to a quality written text (Mirhosseini, 2009). One of these stages is the generation of ideas and creation of content, which is one of the cognitive processes involved in the composing process (Flower and Hayes, 1981). For this stage to be successful and worthwhile, the writer must engage in real purposeful communication and experiment with the language as much as possible. Whereas this stage is almost automatic for those who are writing in their first language, it poses great difficulties for writers in EFL (Weigle, 2005).

An additional hindrance at this stage is the anxiety and apprehension that foreign language writers experience (Lee, 2005). As such, teachers do not only try to equip students with the necessary academic writing skills but also seek ways to address and lower these factors. By referring to students, Johns (1995) also acknowledges that trying to create authors even though they are not ready as second language writers ignores the reality of the situation. Thus, first developing students as confident writers and lessening their apprehension should be the priority. Journal writing, in this respect, offers students the opportunity to practice the skill of writing in a less-threatening writing task and gives them a chance to generate ideas with a real communicative purpose. 
This study aims to examine and re-evaluate the prewriting stage of the writing process: helping students to set a positive mindset by inculcating the habit of 'writing-only', without the burden and stress of academic expectations. In other words, it aims at increasing students' confidence and fluency by engaging them in the skill of writing, separately from formal class work. Unlike the common practice of approaching writing as an activity that offers teachers language production to focus on surface language use (Hubert and Bonzo, 2019), it is believed that at the initial stages, focusing students on content and meaning only will have an indirect impact on the writing proficiency of students in an EAP setting.

\section{Journal writing}

Within this context, journal writing has been the focus of many studies, hypothesizing that it would help improve writing proficiency in the EFL environment (Lagan, 2000; Tin, 2004; Tuan, 2010; Alexander, 2001). Being non-judgmental, journal writing is invaluable; it offers students the chance to experience writing as an expressive rather than completed activity without being judged on their mistakes, organization, content, or linguistic capabilities. As such, it is seen as a very powerful and facilitating way to improve general writing skills. Furthermore, journal writing promotes content creation and organization while writing. If the activity is prolonged, it leads to more disciplined thinking and greater accuracy (Tuan, 2010). It also serves the communicative function involved in written language use.

There are two different approaches to student journal writing (JW); one with no external audience: i.e. journal writing. Journal writing can be defined 
as a daily written record of a writer regarding their feelings, thoughts, and anything they deem important without the fear of being evaluated, graded or corrected (Barjesteh, Vaseghi, \& Gholami, 2011). The second one requires students to interact with the teacher through their journal entries: i.e. dialogue journal writing (DJW). Dialogue journal writing is seen as "an informal written conversation between the students and the teacher" (Larrotta, 2008, p. 21). Staton (1991) stresses three major elements of dialogue journal writing, which are written communication, dialogic conversation, and responsive relationship (Staton, 1991, p. xvii). Both journal types have frequently been the focus of research as alternative ways to facilitate students' writing performance, engagement in the writing task, student motivation and reduction of students' writing apprehension (Holmes, 1994; Liao and Wong, 2010; Abdolmanafi Rokni \& Seifi, 2013, Peng, 2007).

When considered from a theoretical perspective, especially dialogue journal writing, functions as a social and cognitive activity, which is in line with Halliday and Hassan (1989) who describe learning as a social process; and Swain (1995), who suggests comprehensible output as one of the major factors involved in learning. Journal writing offers students the chance to socially interact with their teacher through the medium of writing and turn this interaction into comprehensible output practice. Finally, the Affective Filter Hypothesis put forward by Krashen (1982) makes journal writing worthwhile as it helps students to freely write without the pressure of mistakes, grades, or judgements.

The literature suggests that both journal writing and dialogue journal writing have a positive impact on not only writing proficiency, but also the 
affective factors involved, such as anxiety, lack of self-confidence and apprehension (Lestari, 2018, Peng, 2007). In addition to its positive impact on the quality of writing, journal writing also strengthens the bonds between the instructor and the students. It serves as an informal communication tool where students find the opportunity to share their experiences, fears, happiness, or other emotions. Furthermore, it also serves as a tool for teachers to understand their students beyond the surface level as individuals and helps them to establish a stronger relationship (Kose, 2005).

Mukti (2016) studied the effectiveness of dialogue journal writing on writing narrative texts with Indonesian students and found that students' writings were positively affected. He also added that students responded positively to the journal writing activity. Likewise, Lestari (2018) found that Indonesian learners benefitted from journal writing positively in the sense that their attitudes became positive, and there was improvement in students' descriptive written products. Dabbagh (2017) investigated the effect of dialogue journal writing on the writing proficiency of Iranian EFL learners and found that the experimental group did much better on content, organization and vocabulary. David, Azman and Ming (2018) focused on the effect of journal writing on lowering Malaysian students' writing anxiety and concluded that it had a positive effect. (Madkour (2016) looked at digital dialogue journal writing with university students in Saudi Arabia to see its effects on writing and found that there was significant improvement in style and vocabulary choice. Noyan and Kocaoğlu (2019) conducted a study with Turkish university students to compare the effect of journal writing via WhatsApp to pen and 
paper journal writing. They concluded that both practices impacted the writing proficiency of the students positively.

The benefits of journal writing are numerous, yet in an EFL setting, these benefits are much more concrete. Learners of English conducting their university studies in a language other than their own not only have to develop confidence in writing, but also need to be able to produce text in an academic setting. As Altinmakas and Bayyurt (2019) and Bacha (2010) point out, students in EFL settings struggle with weak academic writing skills on top of linguistic deficiencies and low motivation. Therefore, helping students to develop their writing skills, gain confidence and adopt a positive attitude potentially has a direct impact on their achievement.

Along with all its benefits, journal writing poses some problems, too. One of the drawbacks of integrating journal writing into the writing curriculum is getting students to write regularly. Especially, if journal writing is done on a voluntary basis, students tend to withdraw from the task in the long run. Consequently, it is important to find alternative incentives other than grading to make students continue writing entries. In addition to withdrawal, Hapsari, Santosa and Asib (2018) point out students' problems finding ideas to write about in a given time, which can affect the effectiveness of journal writing. Finally, the burden that it creates on the teacher is a handicap, especially in crowded classrooms. If the teacher is giving feedback to students' entries: i.e. dialogue journal writing, it might impact the willingness of the teacher negatively (Hapsari, Santosa and Asib, 2018). Finally, journal entries run the risk of being too personal. In such cases, the teacher might find it difficult to write comments, or students might react to the feedback received (Rana, 2018). 
Studies in the area of journal writing mainly center around its effect on students' writing proficiency, student attitudes, motivation or self-confidence. Not many studies consider the potential effect it might have on the teacher who is implementing journal writing or dialogue journal writing in their classes, yet it is a mutual activity in which students write and teachers act as the audience and give feedback. In this present research, this aspect has been taken into consideration and teacher attitude has been integrated as one of the variables.

This study investigates the effects of two types of free-writing activities: a) journal writing and b) dialogue journal writing on Turkish students' writing proficiency, and attitudes towards academic writing. It further explores the effects of dialogue journal writing on the student-teacher relationship. The following research questions form the basis of the study: Do journal writing and dialogue journal writing impact students' writing proficiency? Do journal writing and dialogue journal writing impact students' attitudes towards academic writing? Does dialogue journal writing impact the teacher's attitudes towards students' behavior and engagement?

The first research question has a quantitative orientation whereas the last two focus on qualitative data eliciting the affective factors involved in the process, both for the students and the teacher.

\section{RESEACH METHOD}

An experimental design was followed to shed light on the answers of the research questions guiding the study. Experimental methods aim at discovering the effect of one variable on another to test the effectiveness of the 
intervention technique (Hyland, 2016). Here, the effectiveness of journal writing and dialogue journal writing on students' writing proficiency and attitudes is tested.

\section{Participants of study}

The study was conducted at an English-medium foundation university in Izmir, Turkey. The participants were 76 undergraduate students enrolled at different departments taking ENG 101, an English for Academic Purposes (EAP) freshman English course. The research was conducted as part of the program and carried out in the normal teaching setting. Freshmen students were purposely chosen, as these were students beginning to learn academic writing.

The 76 students were enrolled in three different sections of the same course. Students were expected to be at similar proficiency levels (B2), after passing the English proficiency test at the beginning of the academic year. Furthermore, the groups' pre-test results also indicated comparable writing proficiency levels. As such, each section was randomly assigned as Control, Experimental-A (DJW) and Experimental-B (JW) groups.

Control Group: The control group consisted of 26 students ranging in age from 17 to 22 . There were 13 female and 13 male students. Fourteen students were enrolled at the Faculty of Engineering, 6 at the Faculty of Business, 3 at Law Faculty and 3 at the Faculty of Arts and Sciences.

Experimental group A (DJW): The second group consisted of 24 students ranging in age from 18 to 23 . There were 8 female and 16 male 
REGISTER JOURNAL

Vol. 13, No. 1, (2020), pp.1-48

p-ISSN: 1979-8903 ; e-ISSN : 2503-040X

Website: http://journalregister.iainsalatiga.ac.id/index.php/register/

students. Thirteen students were from the Faculty of Engineering, 4 from the Faculty of Communication, 4 from Business, and 1 each from Fine Arts, Culinary Arts and Arts and Sciences. As the journal entries in this group were collected by the teacher, students' consent to use them for the study was taken at the end of the research.

Experimental group B (JW): The last group consisted of 26 students ranging in age from 18 to 28 . Twelve of the students were female and 14 were male. Seven were studying at the Faculty of Engineering, 6 at Fine Arts, 6 at Business, 5 at the Faculty of Law, and 1 each at Communication, and Arts and Sciences. Table 1 shows the details of the groups.

Table 1 Participant demographics

\begin{tabular}{lllllll}
\hline & \multicolumn{2}{c}{ Control Group } & \multicolumn{2}{c}{ Exp. Group-A } & \multicolumn{2}{c}{ Exp. Group-B } \\
\hline Female & $\mathrm{n}$ & $\%$ & $\mathrm{n}$ & $\%$ & $\mathrm{n}$ & $\%$ \\
\hline Male & 13 & 50 & 8 & 33.33 & 12 & 46.15 \\
\hline Faculties & 13 & 50 & 16 & 66.66 & 14 & 53.84 \\
\hline Engineering & & & & & & \\
\hline Science and Literature & 14 & 53.84 & 13 & 54.16 & 7 & 26.92 \\
\hline Business & 3 & 11.53 & 1 & 4.16 & 1 & 3.84 \\
\hline Communication & 6 & 23.07 & 4 & 16.66 & 6 & 23.07 \\
\hline Fine Arts & - & - & 4 & 16.66 & 1 & 3.84 \\
\hline Culinary Arts & - & - & 1 & 4.16 & 6 & 23.07 \\
\hline Law & - & - & 1 & 4.16 & - & - \\
\hline TOTAL & 3 & 11.53 & - & - & 5 & 19.23 \\
\hline & 26 & & 24 & & 26 & \\
\hline
\end{tabular}

\section{EAP context of the study}

The ENG 101 course, Academic Skills in English I, is a 14-week compulsory course for first year students at an English medium university in 
Turkey. As all students come with a B2 level of general English, the aim of this course is to further develop students' English background with the more academic style required in their faculty courses. By the end of the course, students are expected to be better equipped to function in their English medium department courses, and better meet the demands in terms of academic skills in English. At Izmir University of Economics, the course text is an in-house published course book, Anchor 1, comprising of four units based on different general academic topics designed to appeal to a wide variety of academic interests. Each unit contains texts related to the theme of the unit in the form of lectures, videos, and academic research papers. Students are required to study the material and produce an output task in the form of a written response to an issue related to the content. They are required to support their own ideas with evidence presented in the input sections of the book.

\section{Data collection instruments}

The data was obtained in the form of a) pre-test and post-test, b) focusgroup interviews with volunteer students, and c) interview with the teacher. Below is a detailed description of the sources of data:

Pre-tests and post-tests

Students were given a writing task in week 5 (after add-drop), which aimed at serving as the pre-test of the study. The pre-test required students to do the following:

'Using information from your course book, together with your own ideas, write an answer of approximately 250 words to the following question: Are colors important in our lives? Why/Why not?' 
REGISTER JOURNAL

Vol. 13, No. 1, (2020), pp.1-48

p-ISSN: 1979-8903 ; e-ISSN : 2503-040X

Website: http://journalregister.iainsalatiga.ac.id/index.php/register/

As the topic 'colors and their importance in our lives' was covered during the lesson and input was provided on different aspects of colors and their effects, students had already had the opportunity to form an opinion, thus content was quite familiar.

The second task, which served as the post-test, was given in the 10th week when the third unit was completed, after input on the topic of production planning and setting up businesses in the form of lectures, research, and videos.

The second writing task necessitated students to:

'Using information from your course book, together with your own ideas, write an answer of approximately 250 words to the following statement: Explain the most important factors involved in the development of either a traditional or a virtual company.'

Pre- and post-test writings were graded using the in-house writing rubric, in use for several years. Students were introduced to the rubric at the beginning of the course and were familiar with its requirements. The highest possible score was 30 points, and consisted of the following areas and weighting, as shown in Table 2.

Table 2 Institutional grading rubric

\begin{tabular}{lllll}
\hline Organization & Content & Fluency & Accuracy & Total \\
\hline 8 points & 10 points & 8 points & 4 points & 30 points \\
\hline $26.7 \%$ & $33.3 \%$ & $26.7 \%$ & $13.3 \%$ & $100 \%$ \\
\hline
\end{tabular}


Organization refers mainly to the academic conventions that need to be followed, like writing topic sentences, building the body and concluding the text. Content evaluation is based on the quality of the written response given to the question, i.e. evidence and support provided to back up the topic. Fluency reflects the coherence and cohesion within the text; finally, accuracy refers to the variety and accurate use of lexis and structure.

\section{Focus group meetings}

To examine the participants' reactions, at the end of the term, the researcher conducted semi-structured focus-group meetings with eight volunteers from each group. The purpose of the focus group meetings with the students was to understand whether journal writing or dialogic journal writing had an impact on their attitudes towards academic writing in general. The meetings were guided by the following themes: a) attitude towards writing, b) course impact on students writing, c) specific areas of improvement; i.e. content generation, accuracy, writing fluency and organization, d) useful class activities, and e) change in attitudes towards writing.

In addition to these five themes, students were asked to write down one adjective they would use to describe the activity of academic writing. The 45minute focus group meetings were recorded and transcribed for analysis.

\section{Teacher interview}

At the end of the semester, an unstructured interview was held with the teacher to understand her perspectives on journal writing and dialogue journal writing. The aim was to elicit the teacher's attitude towards the experience, and 
whether it affected her teaching, or approach to students. The interview lasted about an hour and the responses recorded in note form, were subjected to an explorative thematic analysis. The analysis was done by two independent raters, and coding of utterances was based on emerging themes.

\section{Experimental set up}

The study was done with three groups of students, randomly assigned as control, experimental-A and experimental-B. The following section describes the experimental set-up for the three groups.

\section{Control group}

Twenty-six students enrolled in this group followed the 14-week program and carried out the writing assignments required as part of the course. There was no mention or encouragement of any form of journal writing. As such, this group received no special or different instruction, and simply followed the EAP programme.

\section{Experimental groups}

In this study, there were two experimental groups. In one, the teacher collected and reviewed the journal entries, thus teacher presence was a potential audience; in the other, journal entries were not submitted to the teacher. The aim was to determine whether the teacher, as the audience, had any effect on the students. Hamp-Lyons and Haesley (2006) suggest that writing intended for the eyes of another, especially the teacher, creates learner 
discomfort and anxiety. The involvement of Experimental group-A and Experimental Group-B was expected to shed light on this issue.

\section{Experimental Group A- Dialogue Journal Writing}

Twenty-four students enrolled in this group followed the 14-week program, including the writing assignments required. As the first week of class involved introductions and familiarization with the course, the implementation of journal writing was delayed until after the $3^{\text {rd }}$ week. At the beginning week 4, students were given a notebook to record their journal writings. It was explained that, as writing is no longer an activity that people (especially students) perform, to reverse this trend, each week they would be asked to write a five-minute free-writing entry in the notebook. They were told to focus on their thoughts, rather than accurate language. To prevent students from struggling to come up with ideas, no word limits were given regarding the length of the entries. It was also stated that their books would be collected at the end of each week purely to prevent the books from getting lost or forgotten, and that writing would not be graded. There were no limits as to the length of their entries.

Over the course of the term, students participated in 11 five-minute writing sessions at the end of the class. Students were given responses to their entries only concerning the actual content, and not grammatical accuracy. Of the 24 students, 18 wrote on a regular basis, completing all 11 entries. The remaining six wrote between 6 and 8. By the end of the term, a dialogue had emerged between the individual students and the teacher, who responded with comments such as : 'Hope this week is better.', 'I'm glad you had a better 
REGISTER JOURNAL

Vol. 13, No. 1, (2020), pp.1-48

p-ISSN: 1979-8903 ; e-ISSN : 2503-040X

Website: http://journalregister.iainsalatiga.ac.id/index.php/register/

week.', 'I hope you've started your Spanish course by now.' 'happy birthday' 'How was your party?'. There were also plenty of longer comments such as 'It sounds like you have got your motivation back. This is wonderful. Maybe it's the power of pop music. I hope you keep this energy up to get you through the term and final exams.' (See Appendix 1 for sample journal entries with feedback).

Experimental Group B - Journal Writing

Twenty-six students enrolled in this group followed the 14-week program including the writing assignments required. As with experimental group A, the journal writing could not be started until the end of the third week of the term. Unlike Experimental group-A, in this group, students were not supplied with a notebook but were asked to use paper to free write for 5 minutes. As with the previous group, a rationale was supplied; students were told to record their thoughts without focusing on language accuracy. No instruction was given to submit papers to the teacher. After finishing, they could leave with their papers. Students were free to keep or dispose of them. No word-limit was set about journal entry length.

In total, 11 five-minute writing sessions were undertaken. Of 26 students, only 5 completed all 11 entries. Two students wrote very few entries, and the rest wrote about 6 to 8 . After two such writing sessions, one student questioned why the instructor was not reading the papers, and therefore, students were given the option to submit their entries. The few students who did so received feedback only concerning the content; language errors were not mentioned. 


\section{RESULTS \& DISCUSSION}

\section{Writing proficiency}

The first research question guiding this study was related to the effect of journal writing and dialogue journal writing on students' writing proficiency. To be able to answer this question, paired samples test was done for the pre- and post-test scores of all three groups. Table 3 shows the pre- and post-test results for the control group.

Table 3 Paired samples test-control group

\begin{tabular}{|c|c|c|c|c|c|c|c|c|c|}
\hline & & \multicolumn{5}{|c|}{ Paired Differences } & \multirow[b]{3}{*}{$\mathrm{t}$} & \multirow[b]{3}{*}{ df } & \multirow{3}{*}{$\begin{array}{l}\text { Sig. (2 } \\
\text { tailed) }\end{array}$} \\
\hline & & \multirow[b]{2}{*}{ Mean } & \multirow{2}{*}{$\begin{array}{l}\text { Std. } \\
\text { Deviation }\end{array}$} & \multirow{2}{*}{$\begin{array}{l}\text { Std. } \\
\text { Error } \\
\text { Mean }\end{array}$} & \multicolumn{2}{|c|}{$\begin{array}{l}95 \% \text { Confidence } \\
\text { Interval of the } \\
\text { Difference }\end{array}$} & & & \\
\hline & & & & & Lower & Upper & & & \\
\hline $\begin{array}{l}\text { Pair } \\
1\end{array}$ & $\begin{array}{l}\text { Writing1 } \\
\text { - } \\
\text { Writing2 } \\
\end{array}$ & -3.950 & 19.127 & 4.277 & -12.902 & 5.002 & -.924 & 19 & .367 \\
\hline
\end{tabular}

The paired samples test shows that there is no meaningful difference between the pre- and post-test results of the control group $(0.367>0.05)$. The average writing score for the pre-test in this group was 80.05 and post-test average was 84.00. Despite an increase, it reflects no statistical significance. It can be concluded that the control group students benefitted from the instruction and made a moderate improvement. 
REGISTER JOURNAL

Vol. 13, No. 1, (2020), pp.1-48

p-ISSN: 1979-8903; e-ISSN : 2503-O4OX

Website: http://journalregister.iainsalatiga.ac.id/index.php/register/

The results of the paired samples test for the first Experimental Group are demonstrated in Table 4.

Table 4 Paired samples test-experimental-A

\begin{tabular}{|c|c|c|c|c|c|c|c|c|c|}
\hline & & \multicolumn{5}{|c|}{ Paired Differences } & \multirow[b]{3}{*}{$\mathrm{t}$} & \multirow[b]{3}{*}{ df } & \multirow{3}{*}{$\begin{array}{l}\text { Sig. ( } 2 \\
\text { tailed) }\end{array}$} \\
\hline & & \multirow[b]{2}{*}{ Mean } & \multirow{2}{*}{$\begin{array}{l}\text { Std. } \\
\text { Deviation }\end{array}$} & \multirow{2}{*}{$\begin{array}{l}\text { Std. } \\
\text { Error } \\
\text { Mean }\end{array}$} & \multicolumn{2}{|c|}{$\begin{array}{l}95 \% \text { Confidence } \\
\text { Interval of the } \\
\text { Difference }\end{array}$} & & & \\
\hline & & & & & Lower & Upper & & & \\
\hline $\begin{array}{l}\text { Pair } \\
1\end{array}$ & $\begin{array}{l}\text { Writing1 } \\
- \\
\text { Writing2 }\end{array}$ & -8.500 & 11.814 & 2.411 & -13.489 & -3.511 & -3.525 & 23 & .002 \\
\hline
\end{tabular}

The test analysis shows that there is a significant difference between students' pre- and post-test scores $(0.002>0.05)$. The average writing score for the pre-test in this group was 73.63 and post-test average was 82.13 . It can be claimed that dialogue journal writing and subsequent teacher feedback on the content of the journal entries had positively affected students' writings. To understand which component of writing caused the main difference, t-test was carried out. Table 5 shows the results of the t-test. 
Table 5 T-test results of experimental-A

\begin{tabular}{llllllll}
\hline \multicolumn{7}{l}{ Pre-test (N=24) } & \multicolumn{2}{l}{ Post-test (N=24) } & & \\
\hline Writing & $\mathrm{M}$ & $\mathrm{SD}$ & $\mathrm{M}$ & $\mathrm{SD}$ & $\begin{array}{l}\mathrm{M} \\
\text { difference }\end{array}$ & $\mathrm{t}$ & $\mathrm{p}$ \\
\hline Org & 17.779 & 5.267 & 21.250 & 5.193 & 3.471 & 2.299 & 0.026 \\
\hline Content & 24.579 & 6.852 & 27.638 & 4.949 & 3.058 & 1.773 & 0.083 \\
\hline Fluency & 19.858 & 4.548 & 20.979 & 3.990 & 1.121 & 0.908 & 0.369 \\
\hline $\begin{array}{l}\text { Accurac } \\
\text { y }\end{array}$ & 11.504 & 3.389 & 12.200 & 2.316 & 0.696 & 0.830 & 0.411 \\
\hline
\end{tabular}

The results indicate a significant effect of 'organization' on the overall increase $(0.026>0.05)$. Even though there was an improvement in the post-test in all four rubric areas: i.e. organization, content, fluency and accuracy, the major development was reflected in organization.

As for the second experimental group engaged in journal writing, the paired sample test results (Table 6) show no significant difference between preand post-test scores.

Table 6 Paired samples test-experimental-B

\begin{tabular}{|c|c|c|c|c|c|c|c|c|c|}
\hline & & \multicolumn{5}{|c|}{ Paired Differences } & \multirow[b]{3}{*}{$\mathrm{t}$} & \multirow[b]{3}{*}{ df } & \multirow{3}{*}{$\begin{array}{l}\text { Sig. (2 } \\
\text { tailed) }\end{array}$} \\
\hline & & \multirow[b]{2}{*}{ Mean } & \multirow{2}{*}{$\begin{array}{l}\text { Std. } \\
\text { Deviation }\end{array}$} & \multirow{2}{*}{$\begin{array}{l}\text { Std. } \\
\text { Error } \\
\text { Mean }\end{array}$} & \multicolumn{2}{|c|}{$\begin{array}{l}95 \% \text { Confidence } \\
\text { Interval of the } \\
\text { Difference }\end{array}$} & & & \\
\hline & & & & & Lower & Upper & & & \\
\hline Pair 1 & $\begin{array}{l}\text { Writing1 } \\
- \\
\text { Writing2 }\end{array}$ & .091 & 12.943 & 2.759 & -5.648 & 5.829 & .033 & 21 & .974 \\
\hline
\end{tabular}


The pre-test score average of the second experimental group was 82.45. The post-test scores, on the other hand, had an average of 82.36, showing neither an improvement, nor a statistical significance between experimental-B group averages.

Based on the results of the pre-tests and post-tests, it can be said that DJW made the greatest impact on students' academic writing skills. The students in the control group benefitted from the instruction, yet the improvement represented no meaningful difference between their pre- and post-tests. The results of the experimental group, which received treatment in journal writing (Experimental Group-B) exhibited a disappointing result in the sense that they made no improvement in their writing proficiency scores. This may partly be explained by the variable attendance in lessons, as this group had the highest absenteeism of the three. Also, few of the students were involved in the writing of journal entries, knowing that they would not be collected, or read. As highlighted by Asadifard and Koosha (2013) and Ceylan (2019), students do not prefer to write if they do not see a reason or communicative value. Thus, the lack of an audience, in this case the teacher, made a difference to students' perceptions of the journal writing activity. Knowing their entries would neither be collected nor graded, many students withdrew from the activity.

The DJW group, with the highest gain in post-test scores, was further analyzed based on the writing components effective in scoring. The literature on the effects of journal writing suggests that students benefit from this experience more in terms of writing fluency (Holmes and Moulton, 1997; 
Peyton, 2000), but the results of this study only partially support this finding. Students' post-test writing scores show that DJW helped them in all four areas, yet 'organization' improved most, supporting the view that the more students write, the more practice they get in organizing their ideas while writing (Lagan, 2000). An additional reason for the improvement in students' writing scores can be attributed to their self-confidence in writing, which is expected to have developed during the journal writing experience. As Gruwell (2007) also emphasizes, journal writing does not only improve writing skills but also the attitudes of learners towards writing.

\section{Students' attitudes towards academic writing}

To understand whether factors other than journal writing may have had an effect on student writing, members from all three groups were included in the focus group analysis. Thus, a total of three focus group meetings were held. Below is the collection of student responses with samples from their utterances.

\section{Control group}

Eight students participated in the focus group meeting, which lasted 45 minutes. For the control group, the participants are referred to as CSt-1, CSt2...CSt-8 (C=Control Group, St=Student). The first question directed to students was whether they liked writing in English. CSt-3, CSt-5 and CSt-6 indicated that they do not, considering it as a boring activity. For example, CSt5 openly said “I don't like it. It's quite boring". CSt-1, CSt-4 and CSt-8 said they liked it, CSt-2 said she loved writing, claiming "I love it - learn new vocabulary, develop". The remaining student had no clear idea about his attitude. 
When asked about the efficiency of this course, and whether it helped them develop their writing skills, CSt-1, CSt-2, CSt-4, CSt-7 and CSt-8 said it helped them, especially in terms of the writing quizzes in their department courses. CSt-7 said "My quiz grades got better towards the end". CSt-3 mentioned that she learned how to cite and use sources claiming "I used to copy-paste, now I know how to acknowledge studies". CSt-5 wanted writing to be a more casual activity, with less formal vocabulary and complained that "there are too many rules". CSt-6 mentioned that the course was focusing on paragraph writing and not essays, implying that the writings required were shorter than expected.

'Which activities would you have liked to have done more of in the class?' was another focus group question. The majority said that they liked the discussion parts the most, which prepared them for the writing in terms of content. CSt-2 and CSt- 8 specifically highlighted this by saying that "debates and discussions teach a lot of things". None of the students suggested any additional writing activities in this regard.

The last question was about possible changes in students' attitudes towards writing. Only CSt-4 reported a change from hating writing to liking it, which is indicated in his response "I hated it - now I love it". CSt-5 said "it didn't change - I don't like writing...but I know it has improved" suggesting that his attitude had not changed, but he feels he improved. The rest of the group mentioned no change in attitudes, whether these were positive or negative. The adjectives that students were asked to describe writing were as follows: adore, boring x 5, strategic, and it's fun without coercion. 
As a conclusion, it can be stated that control group students benefitted from the course, which is also evident from their score gains between pre- and post-tests. Yet, their attitude towards writing as a skill seems to be more at a mechanical level. The majority of students in the focus group consider writing as a boring skill, indicating low motivation, and a generally negative attitude towards writing. Literature on writing also suggests that it is not a very popular skill and needs to be made more appealing to students. Asadifard and Koosha (2013) make reference to Iranian students' writing reluctance in the EFL setting, and Ceylan (2019), in her study with Turkish EFL students, refers to many factors such as lack of value and limited writing activities, stress or topic familiarity that hinder self-confidence and success in writing.

Experimental group- $A(D J W)$

For experimental group-A, the participants are referred to as EA-St-1, EA-St-2...EA-St-8 (EA= Experimental Group-A, St=Student). The first question elicited students' attitudes towards writing and whether they liked it. Six positive responses clearly indicated a like for writing. EA-St-6 justified his negative response as "mother tongue is Turkish...it is difficult to translate. I like reading comic books so not used to formal writing". EA-St-3 also expressed a negative opinion claiming that it was 'frustrating' to write in English.

Regarding the effect of this course, all students agreed that their writing skills had developed as a result. EA-St-2 commented 'Yes - a fresh startbring my English back', whereas EA-St-7 said that he found the chance to "revise and practice previous learning". EA-St-5 thought the most effective 
REGISTER JOURNAL

Vol. 13, No. 1, (2020), pp.1-48

p-ISSN: 1979-8903 ; e-ISSN : 2503-O4OX

Website: http://journalregister.iainsalatiga.ac.id/index.php/register/

part was the assessed writing tasks. EA-St-1 commented ' $I$ didn't write anything until this time - now I can write what I want'. As to which activities were considered helpful, almost all made reference to the dialogue journal writing activity. EA-St-1 referred to the journal writing: 'Yes absolutely, mostly the free writings we did at the end of the lesson helped me most'. EA-St-4 said 'I didn't find it forced. Write what we want'. EA-St-2 foregrounded sharing her feelings and ideas: 'I shared my feelings with the teacher'. Two students acknowledged that dialogue journal writing was beneficial for learning and practicing new vocabulary, and getting advice on content. Journal writing was also considered useful for remembering the rules of the English language; EASt-1 said that she is 'confident with everyday language, not with academic language', so it is easier to write the journal entry.

As for the components of writing, EA-St-4 and EA-St-5 said that dialogue journal writing made it easier for them to generate content by highlighting "it is easier to think of ideas quickly", EA-St-7 believed that it helped him use the language more accurately, and EA-St-1, EA-St-2 and EASt- 8 said that it helped them organize ideas better and become more fluent by claiming "it did help on language use and writing fluency".

Regarding students' preferences of activities that should have been done more often, EA-St-2 mentioned that he was content with the current situation. EA-St-1 and EA-St-5 mentioned vocabulary study as an area by focusing on "finding the words adverb, adjective versions". EA-St-3 suggested more games and fun activities, and EA-St-6, more discussions during the lessons. 
One of the focus group questions aimed at eliciting the change in students' attitudes towards writing. EA-St-1, EA-St-5, EA-St-7 and EA-St-8 said there was no change in their positive attitude. EA-St-2 said that it changed completely, as he put it: 'at first, I only used to write. Now I'm starting to think what I write, how I write'. EA-St-4 described a change from a negative to positive attitude as she started feeling 'more confident in academic English'. EA-St-6 said that she used to dislike writing, but now was 'slightly' more positive. When students were asked to write an adjective or phrase to describe the skill of writing, the following emerged: happy, amazing, fresh start, bring English back to life, weary, entertaining, thoughtful, and boring.

Overall, the DJW group found journal writing quite effective in many respects. Especially, they appreciated that, as journal writing was not a course requirement, they had the freedom to reveal their feelings, emotions, opinions to their teacher, and considered it as a useful tool to practice vocabulary. The freedom of topic choice in journal writing was also foregrounded by Mukti (2016) as one of the factors that makes dialogue journal writing worthwhile for students. Thus, as highlighted in literature, dialogue journal writing has positive effects on students' writing proficiency, and on overcoming apprehension (Alexander, 2001). Furthermore, the comments from the teacher helped create an authentic purpose for writing. As students of this era rarely use extended writing in their everyday communication, this is considered to be a valuable outcome of dialogue journal writing in terms of student motivation, expressed with positive phrases such as fresh start, and bringing English back to life. Finally, the combination of increased motivation, the strengthened bond 
with their teacher and the freedom of topic choice impacted their writing proficiency (Mukti, 2016).

Experimental group- $B(J W)$

For experimental group-B, the participants are referred to as EB-St-1, EB-St-2 ...EB-St-8 (EB= Experimental Group-B, St=Student).The question on whether or not students enjoyed writing in English yielded positive results. Six said that they liked writing, EB-St-1 and EB-St-7 did not. EB-St-7 justified his opinion, saying 'I believe that when you write, you need to use more information about language than you use while speaking'.

All students gave positive responses about the effectiveness of the course and the impact it had on their writing skills. Especially EB-St-3 talked at length about the effectiveness, concluding 'I am happy that I get this course and even though I didn't work much out of the classroom, I participate in all activities and they improved my language abilities'. EB-St-6 mentioned organization as one of the areas he developed most, stating that 'I used to just write it right away, but now the planning techniques that we learned helps me a lot'. Another student highlighted the importance of reading and taking notes during the lesson as factors for improvement in her writing.

As to which activity they found most useful, almost all mentioned journal writing at the end of the lesson. For EA-St-2, it helped develop vocabulary, and she even mentioned that it benefited her speaking as well as writing, because, as she put it, 'you speak in your mind and write it down. Improves speaking skills - daily life communication with other people'. EB-St8 discussed the psychological effect of journal writing in this codeswitched 
comment: 'End of lesson writing - 'faydall - something you can't say in class - kağılda dökebilirsin' (Eng: end of lesson writing is beneficial. Something you cannot say in class, but you can put on paper).

When asked their opinion on which component of writing they developed the most, all eight students highlighted organization of ideas, coherence, and flow of writing. EB-St-2 and EB-St-4 reported that the journal writings had a positive impact on writing fluency.

For the question about activities they would like more of, EB-St-7 suggested anything other than writing. EB-St-3, EB-St-5 and EB-St-8 indicated the end of lesson journal writing: 'The end of week writings was my favorite activity since we wrote about daily things and what we wanted to talk about other than just book topics'. EB-St-1 mentioned more speaking activities in the course.

Regarding students' attitudes towards writing, six students reported no change in their positive opinions, whereas EB-St-1 expressed no change in his negative opinion. EB-St-7 admitted that he is slightly more positive after the course. The adjectives students used to describe the writing activity were: interesting, beneficial, productive, improving, absurd, improvement, expression, and entertaining.

The JW group expressed positive feelings about writing and the effectiveness of the course. The five-minute journal writing at the end of the lesson was identified as the most popular activity by the students. Even though the entries had no audience, they felt comfortable about being able to write on a topic of their own interest, which gave them a genuine purpose. The positive attitude of the majority shows that journal writing had an indirect impact on motivation. Although, for this group, the post-test scores reveal no 
improvement in their writing proficiency, it certainly seems to have impacted their engagement and self-confidence.

The fact that in both experimental groups, students responded positively to the journal writing activity stresses the expressive paradigm of the writing activity (Hyland, 2016). When writing is treated as a communicative act rather than a completed product, students engage more and develop a more positive attitude towards academic writing.

\section{Teacher's perspective}

The final research question aimed at eliciting the teacher's attitude towards the experience of implementing journal writing into her academic writing lesson. The analysis of the teacher interview generated interesting findings that can be summarized under the following headings: authentic written communication, understanding students, passive protest, change in student attitudes, and extra work.

\section{Authentic communication}

The teacher highlighted that the most important gain of this experience, especially with the DJW group, was the authentic communication between her and the majority of her students. She reported that the content of the journal entries usually centered around asking for advice (e.g. 'how can I improve my vocabulary?', 'I have too much work to do...how can I do it?'), sharing good news (e.g. going to a job interview), sharing past experiences, goals and future plans, explaining their life outside of the classroom (e.g. parents coming to 
stay, how difficult life is on your own), sharing observations about life (e.g. how people take things for granted - after living on their own for the first time and having no hot water...how getting the hot water made him so happy), explaining injustices in the world, explaining/recommending a film or music, discussing feelings about the class, talking about the workload of courses sharing worries and areas of anxiety. She pointed out these were instances of genuine communication expressed in the medium of writing.

The expressive and communicative nature of writing (Hyland, 2016) affected both the students and the teacher positively. The fact that real communication was the key to the content of the journal entries, was also confirmed by the teacher.

\section{Understanding students}

In relation to the content, the teacher highlighted many instances of better understanding of students as individuals. She did not engage students in journal writing in the control group, and did not read the journals written by experimental group-2; nevertheless, she noted that 'even though I did not have a dialogue with these groups in the same way as the other group, I was more aware of what might be happening to them outside of the classroom because they were in the same faculties as my other group. I was also more tolerant towards them when it came to a lack of interest that sometimes happens in the classroom'. She added that she was better able to sympathize and had more background information to help her engage and connect with her students. She had not consciously focused on these issues before. 
As Lestari (2018) also pointed out, dialogue journals are a means for individualized feedback and, as such, help teachers gather more information about their students. The reflection of the teacher in this study clearly showed that knowing more about the students helped her understand them better.

\section{Passive protest}

Another interesting area that emerged from the interview was the fact that two students adopted a passive protest type of behavior regarding journal entries, particularly in Experimental Group-A, where these were being collected. One student refused to write his thoughts in English, but rather than doing nothing, used a variety of other forms, mediums or languages to communicate, such as drawing pictures to illustrate his feelings, recreating a dialogue from a famous children's movie (The Bee Movie), writing out a children's rhyme (What Shall we do with the Drunken Sailor?), creating a picture from words studied in the class (creating a face using only reporting verbs), writing in morse code/computer code and writing in French and Italian (see Appendix 2 for sample entries). Rather than reacting, the teacher accepted this as his way of communicating his thoughts. Another student, when given the notebook for diary entries in experimental group-A, initially described it as childish, like in primary school, but became engaged in writing as the course progressed.

Some studies confirm that not all students have a positive approach to journal writing, which may result from lack of time, motivation, or dislike (Hapsari, Santosa and Asib, 2018). Here, too, a few students initially resisted or found alternative ways to approach task. As the key is to use writing as a 
way for communicating, the teacher gave students the freedom to choose the medium they felt most comfortable with.

\section{Change in student attitudes}

The teacher said that she could clearly notice a change in students' attitude towards writing in the experimental groups, in particular, in the dialogue journal writing group. She quotes one student who, initially had a negative attitude, but once engaged in journal writing, asked 'Teacher, if you have time, can I write a bit more?' and she then wrote for 15 minutes, staying after class was over. The teacher emphasized that most students were less intrinsically motivated to write the academic tasks required in the course, yet more willing to do the much less constrained journal writing. She said that this did not disturb her, as she believed they were gaining confidence in terms of writing, which they could eventually transfer to academic writing.

A positive attitude was one of the outcomes of the focus group meetings with the students, too. The response of the teacher verified this. Besides the positive effect of journal writing on writing proficiency of students, the literature supports the affective nature of journal writing as well (Lestari, 2018; Gruwell, 20017; Mukti, 2016; Debbagh, 2017). One of the most valuable effects of this study was the change of student attitudes towards writing, which was also quite overt and noticeable for the teacher.

\section{Extra work}

Despite all the benefits, the teacher also mentioned that it was a timeconsuming task, especially in larger classes. As the students wrote every week, 
she tried to finish her responses to all entries within the week, so students could see them before the new entry. However, her final assessment of the experience of journal writing, and the burden it presented, was that it had been worthwhile:

'Reading the notebooks and writing comments did take some time, but I always looked forward to reading the entries and never ever viewed it as a burden. The time spent reading and replying was time well spent and felt like I was contributing something to the class, students and myself in the process. It helped me change the way of approaching some issues in the classroom and gave me a deeper understanding of what students need and want from an instructor.'

Among the few drawbacks of journal writing, increased workload on the side of the teacher is the most prominent one (Hapsari, Santosa and Asib, 2018; Rana, 2018). It goes without saying that more work is involved in reading journal entries and giving individualized feedback on the various topics students may want to write about. Yet, the gains far outweigh the burdens for the teacher in this study. However, it should be kept in mind that the class sizes of the groups in this study ranged between 24-26. It could have been less manageable with larger groups. Therefore, class size seems to be a determinant factor when applying dialogue journal writing in the EFL classroom.

\section{CONCLUSION}

There have been a variety of attempts to facilitate the improvement of writing skills, especially targeted towards improving writing fluency, particularly in EFL settings. As mentioned earlier, extended writing is not a skill in daily use, yet students at English medium universities are expected to perform writing tasks in English quite frequently in academic settings. Journal 
writing and dialogue journal writing were introduced as alternative approaches to writing designed to lessen the writing apprehension of students, to engage them in authentic written communication, and to get them into the habit of writing freely.

Especially dialogue journal writing promotes students' writing development on various grounds. It serves as a tool for students to practice the language intensively in a non-threatening environment by lowering affective factors involved in language production. Furthermore, it gives students the chance to produce comprehensible output using their existing knowledge. Finally, dialogue journal writing enhances real communication between the teacher and the students, highlighting the expressive function of writing.

The results of this study refer to a two-fold gain. First, students were able to practice and develop their writing skills by engaging in authentic writing within a more flexible environment in terms of topic choice and teacher feedback, which was limited to content only. Even though the writings that students produced for the journals were non-academic in nature, there is evidence that creating such opportunities will eventually result in an indirect impact on their academic writing, as students develop confidence and fluency. As part of the writing process, students are expected to generate content, ideally with little apprehension or anxiety. The journal writing experience lays the ground for students to practice this in a non-threatening setting.

The second outcome of this study is related to the teacher engaged in this journal writing experience and her professional growth. Despite the extra burden, and the reluctance of some of the students, journal writing offers gains, 
including invaluable insights to the teacher on the students as individuals. Once connected to them through authentic communication, seeing the change in approaches and attitudes to the teacher, based on more personal understandings, the gains outweigh any extra burden. In some way, the engagement in student entries has extended the teacher's contact time with her students, which is considered important for student growth as well.

This study focused specifically on the affective sides of writing and whether lowering these and creating a bond with the teacher would indirectly affect students writing proficiency. No analysis was done to examine the direct effect of journal writing on students' academic writing fluency. Further research is needed to uncover the specific areas of writing proficiency that are impacted the most by journal writing.

\section{REFERENCES}

Abdolmanafi Rokni, S. J., \& Seifi, A. (2013). The effect of dialog journal writing on EFL learners' grammar knowledge. Journal of Language and Linguistic Studies, 9(2), 57-67.

Alexander, N. (2001). A long day's journal into night: A primer on writing dialogue journals with adolescent ESL students. In J.I. Burton \& M. Carroll (Eds.), Journal writing: Case study in TESOL practice series (pp. 23-35). Alexandria, VA: Teachers of English to speakers of Other Languages. 
Altınmakas, D. \& Bayyurt, Y. (2018). An exploratory study on factors influencing undergraduate students' academic writing practices in Turkey. Journal of English for Academic Purposes. 88-103.

Asadifard, A. \& Koosha, M. (2013). EFL instructors' and student writers' perceptions on academic writing reluctance. Theory and Practice in Language Studies, 3(9), 1572-1578.

Bacha. N. N. (2002). Developing learners' academic writing skills in higher education: A study for educational reform. Language and Education, 16(3), 161-177, DOI: 10.1080/09500780208666826.

Barjesteh, H., Vaseghi, R. \& Gholami, R. (2011). The effect of diary writing on EFL college students' writing improvement and attitudes. Paper presented at International Conference on Languages, Literature and Linguistics, Singapour: IACSIT Press

Breeze, R. (2012). Rethinking academic writing pedagogy for the European university. Amsterdam: Rodopi.

Ceylan, O. N. (2019). Student perceptions of difficulties in second language writing. Journal of Language and Linguistic Studies, 15(1), 151-157.

Dabbagh, A. (2017). The effect of dialogue journal writing on EFL learners' descriptive writing performance: a quantitative study. International Journal of Applied Linguistics \& English Literature, 6(3), 71-80.

David, A. R., Azman, H. \& Ming, T. S. (2018). Investigating online dialogue journal writing impacts on low proficiency students' writing anxiety. 
REGISTER JOURNAL

Vol. 13, No. 1, (2020), pp.1-48

p-ISSN: 1979-8903 ; e-ISSN : 2503-040X

Website: http://journalregister.iainsalatiga.ac.id/index.php/register/

International Journal of Language Education and Applied Linguistics, $8(2), 71-81$.

Flower, L. \& Hayes, J. R. (1981). A cognitive process theory of writing. College Composition and Communication, 32(4), 365-387.

Gruwell, E. (2007). The freedom writers diary. New York: Broadway Books.

Hamp-Lyons, L. \& Heasly, B. (2006). Study writing (2nd Ed.). Cambridge: Cambridge University Press.

Halliday, M. A. \& Hassan, R. (1989). Language context and text: aspects of language in a social semiotic perspective. Oxford, UK: Oxford University Press.

Hapsari, C. T., Santosa, R. \& Asib, A. (2018). Dialogue journal: Exploring its use to teach writing. International Journal of Multicultural and Multireligious Understanding, 5(4), 184-195.

Hawkey, R. \& Barker, F. (2014). Developing a common scale for the assessment of writing. Assessing Writing 9, 122-159. doi:10.1016/j.asw.2004.06.001

Holmes, V.L. (1994). Six adult university ESL students' perspectives of dialogue journal writing: A multiple case study. Unpublished doctoral dissertation, University of Nevada, Las Vegas.

Holmes, V.L., \& Moulton, M.R. (1997). Dialogue journals as an ESL learning strategy. Journal of Adolescent \& Adult Literacy, 40(8), 616-621. 
Hubert, M. D. \& Bonzo, J. D. (2019). Theory and practice in foreign language writing instruction. Journal of Second Language Teaching, 7 (1), 135159.

Hyland, K. (2003). Genre-based pedagogies: a social response to process. Journal of Second Language Writing, 12, 17-29.

Johns, A. M. (1995). Genre and pedagogical purposes. Journal of Second Language Writing, 12, 17-29.

Kose, E. (2005). Impact of dialog journals on language anxiety and classroom affect. The institute of Economics and social science. Unpublished Master's Thesis, Ankara: Bilkent University.

Krashen, S. D. (1982). Principles and practice in second language acquisition. Oxford: Pergamon Press.

Kruse, O. (2013). Perspectives on academic writing in European higher education: Genres, practices, and competences. Revista de Docencia Universitaria, 11(1), 37-58.

Lagan, J. (2000). College writing skills. London: Longman.

Laratto, C. (2008). Written conversations with Hispanic adults developing English literacy. Adult Basic Education and Literacy Journal, 2(1), 1323.

Lee, S. Y. (2005). Facilitating and inhibiting factors on EFL writing: A model testing with SEM. Language Learning, 55, 335-374. 
Lestari, Y. (2018). Dialogue journals in improving students' writing descriptive texts. Journal of English Education, Literature and Linguistics, 1(1), 23-32.

Liao, M and Wong, C. (2010). Effects of dialogue journals on L2 students' writing fluency, Reflections, Anxiety, and Motivation. Reflections on English Language Teaching, 9(2), 139-170.

Madkour, M. (2016). The effect of digital dialogued journaling on improving English writing: a linguistic communicative approach. English Language Teaching, 9(8), 241-263.

Mirhosseini, S. A. (2009). For our learn of English: Dialogue journal writing in EFL education. PROSPECT, 24(1), 40-47.

Mukti, A. (2016). The effectiveness of dialogue journals in improving the skill in writing narrative texts. IJEE, 3(1), 1-14.

Noyan, E. \& Kocaoğlu, Z. (2019). Developing EFL writing skills through WhatsApp dialogue journaling. Advances in Language and Literary Studies, 10(2), 38-48.

Peng, C. Y. (2007). The effect of online journal writing on writing performance and writing self-efficacy of undergraduate students. Unpublished Master's Thesis. Chaoyang University of Technology, Taichung, Taiwan.

Peyton J.K. (2000). Dialogue journals: Interactive writing to develop language and literacy. ESL Resources: Digests. National Center for ESL Literacy 
Education. Retrieved February 27, 2020, from http://www.cal.org/caela/esl_resources/digests/Dialogue_Journals.html

Rafida, T. (2017). The integration of vocabulary and effective sentence mastery towards students' argumentative writing skills. Register Journal, 10 (1), 1-11.

Rana, L. B. (2018). The use of dialogue journals in an ESL writing class from Vygotskyan perspective. Journal of NELTA Surkhet, 5, 1-14.

Roselini, S. (2014). How to help young English language learners love writing retrieved February, 28, 2020 from https://www.britishcouncil.org/voices-magazine/how-help-youngenglish-language-learners-love-writing

Seaboyer, J. \& Barnett, T. (2019). New perspectives on reading and writing across the disciplines. Higher Education Research \& Development, 38(1), 1-10, DOI: 10.1080/07294360.2019.1544111

Staton, J. (1991). Creating an attitude of dialogue in adult literacy instruction. In J.K. Peyton \& Staton (Eds.), Writing our lives: Reflection on dialogue journal writing with adults learning English. New Jersey: Center for Applied Linguistics.

Swain, M. (1995). Three functions of output in second language learning. In G. Cook \& B. Seidhofer (Eds.), Principle and practice in applied linguistics (125-144). Oxford: Oxford University Press. 
REGISTER JOURNAL

Vol. 13, No. 1, (2020), pp.1-48

p-ISSN: 1979-8903; e-ISSN : 2503-O4OX

Website: http://journalregister.iainsalatiga.ac.id/index.php/register/

Tin, T.B. (2004). Creative writing in EFL/ESL classrooms. Universiti Putra Malaysia Press.

Tuan, L. T. (2010). Enhancing EFL learners' writing skill via journal writing. English Language Teaching, 3(3), 81-88.

Weigle, S. C. (2005). Second language writing expertise. In Johnson, K. (Ed.), Expertise in second language learning and teaching (pp. 128-149). New York, NY: Palgrave Macmillan. 
APPENDIX-1 Samples of student diaries and teacher feedback

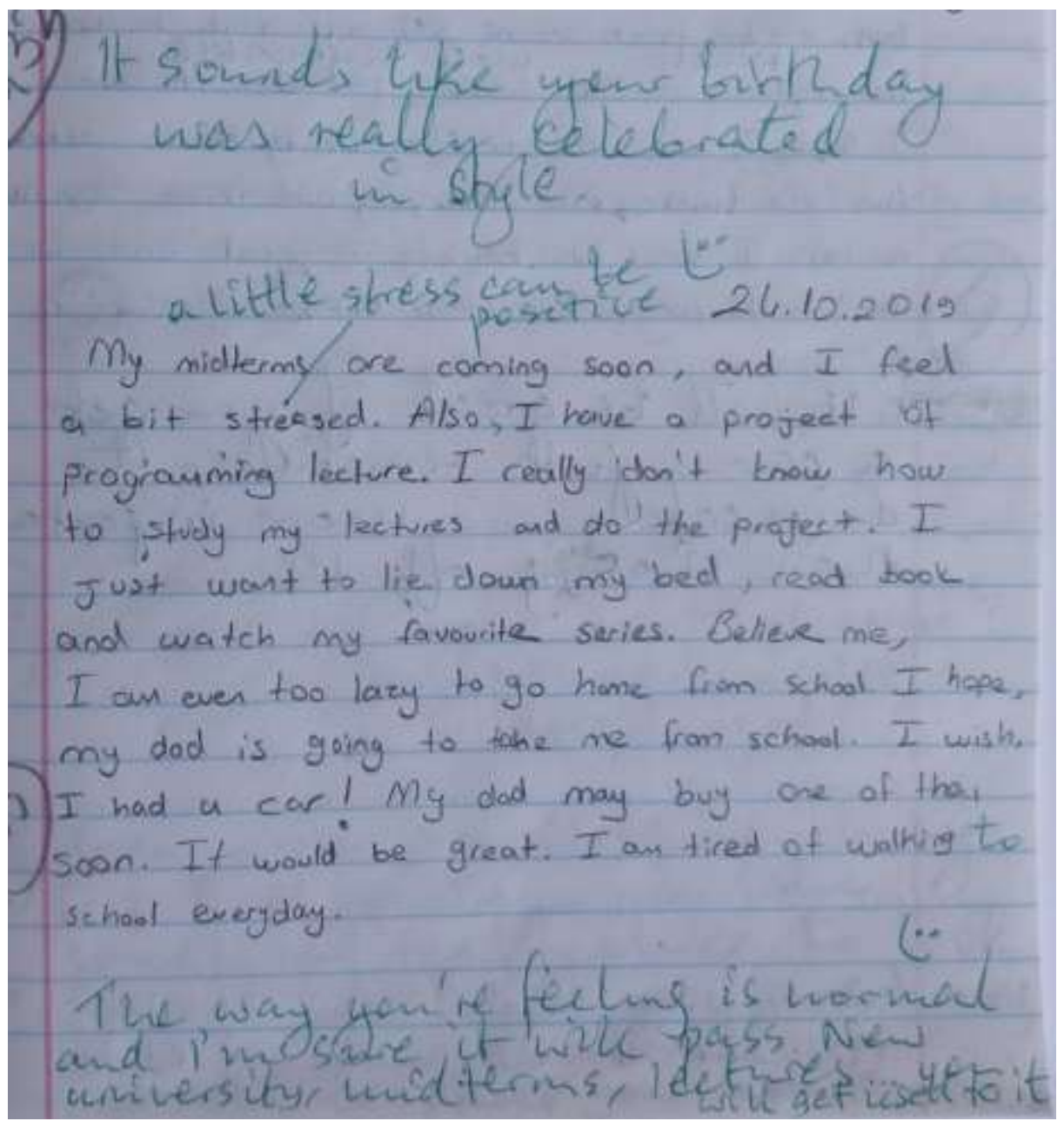


REGISTER JOURNAL

Vol. 13, No. 1, (2020), pp.1-48

p-ISSN: 1979-8903 ; e-ISSN : 2503-040X

Website: http://journalregister.iainsalatiga.ac.id/index.php/register/

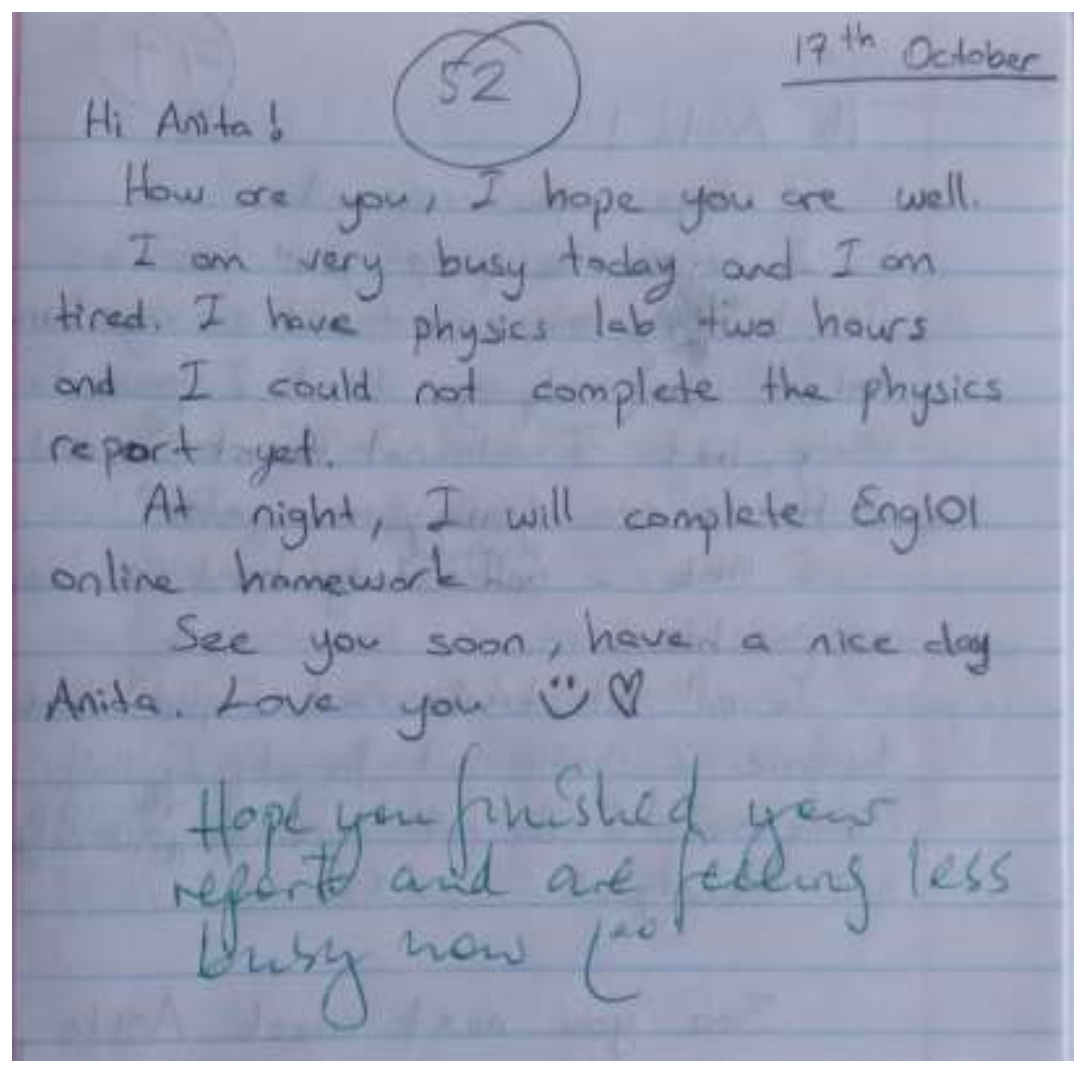


Aynur Yürekli, Anita Afacan

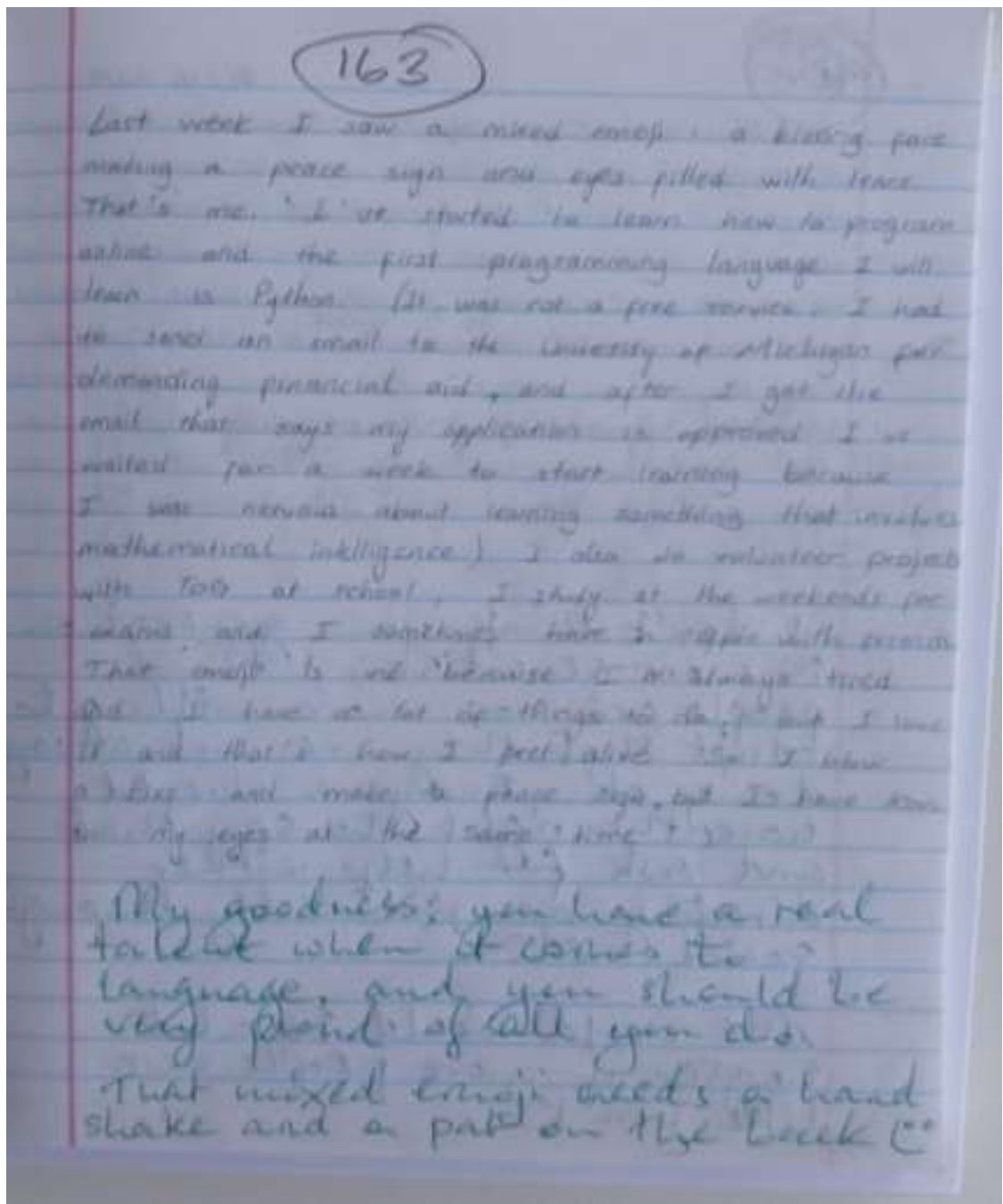


REGISTER JOURNAL

Vol. 13, No. 1, (2020), pp.1-48 p-ISSN: 1979-8903; e-ISSN : 2503-O4OX

Website: http://journalregister.iainsalatiga.ac.id/index.php/register/

APPENDIX-2 Samples of extra-ordinary student entries

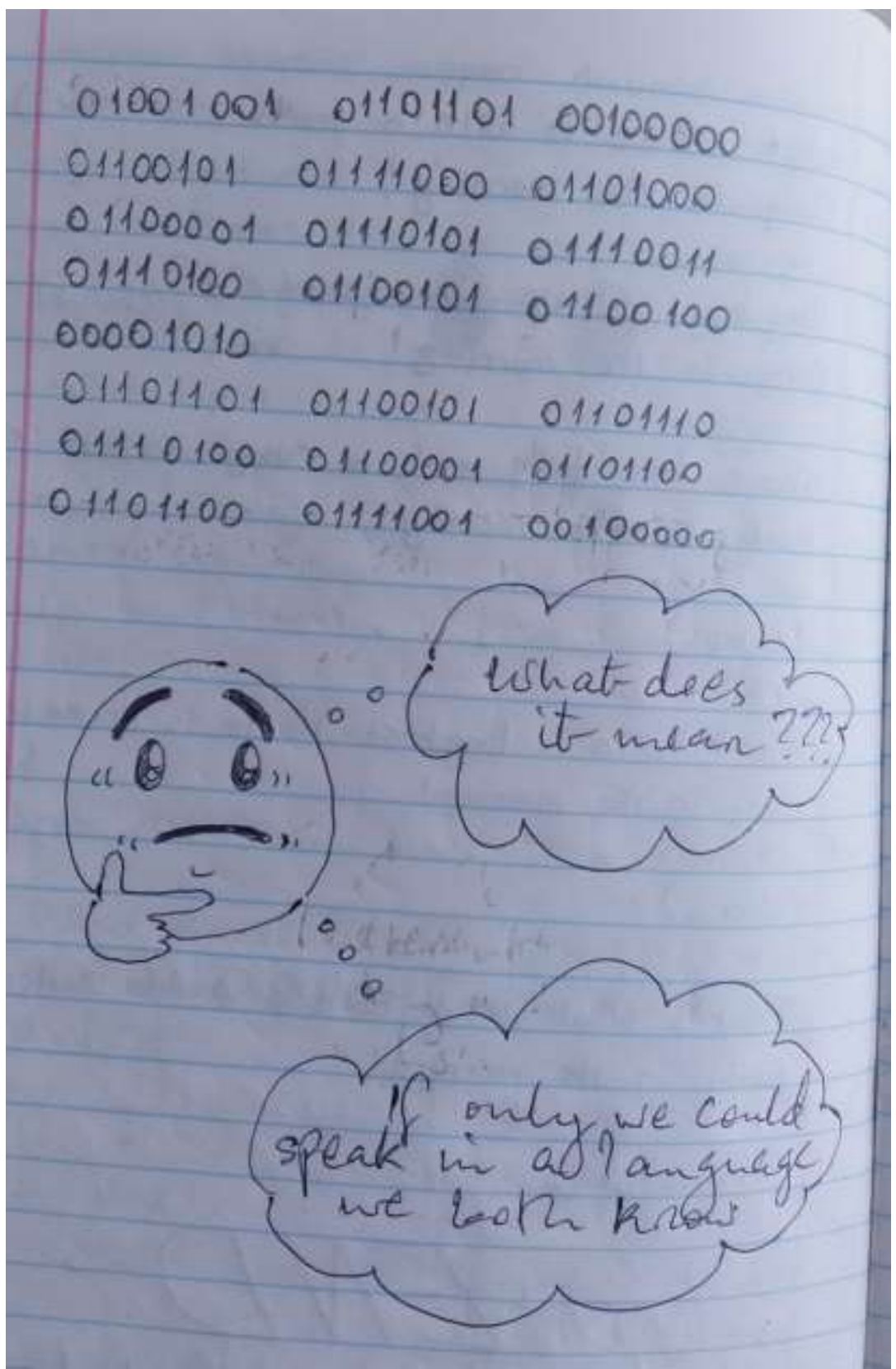




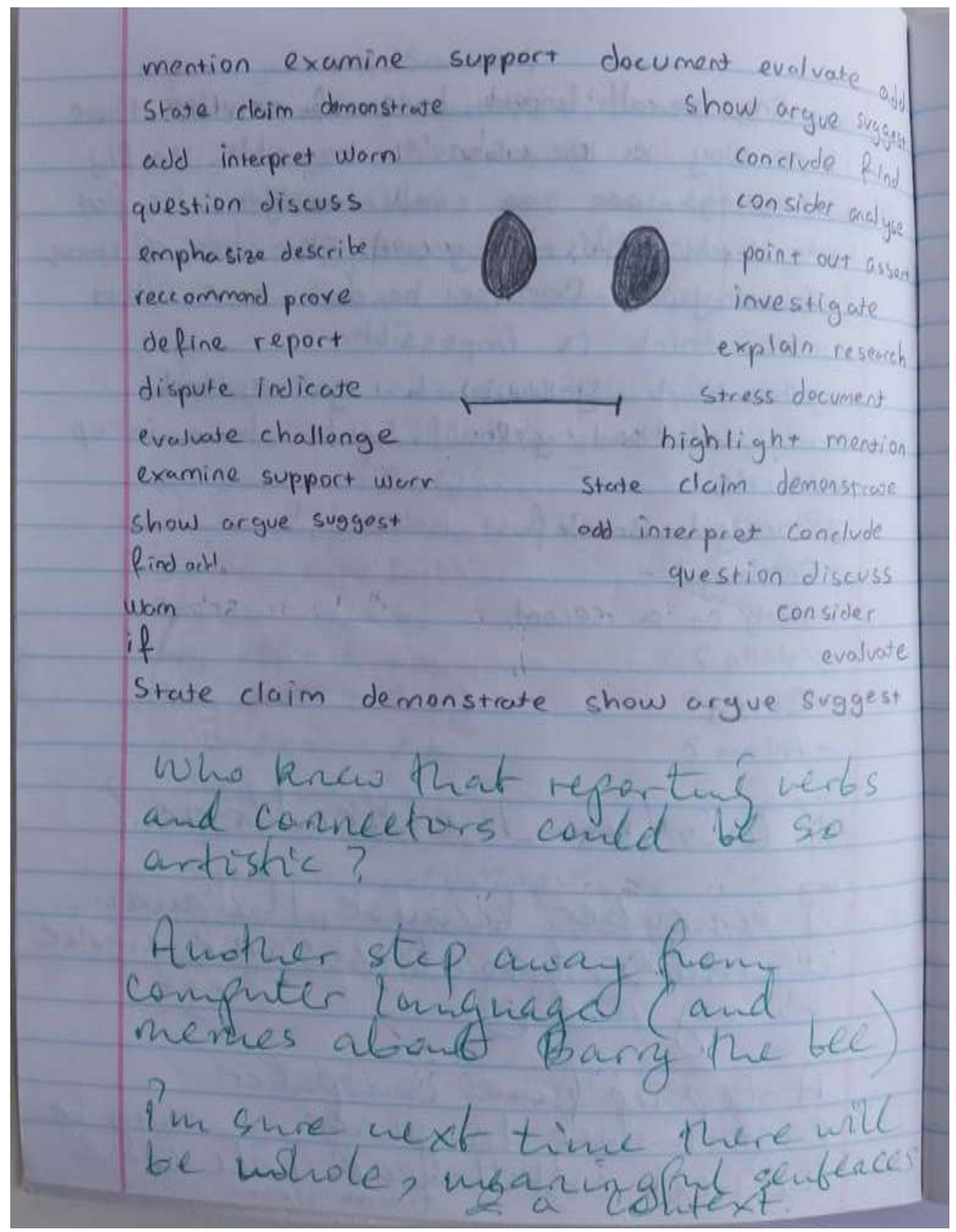

